\title{
Atheta strandiella Brundin, 1954 (Coleoptera: Staphylinidae) - a species newly recorded in Poland
}

\author{
Rafał RUTA ${ }^{1}$, Andrzej MELKE ${ }^{2}$, Karol KOMOSIŃSKI $^{3}$, Paweł SIENKIEWICZ ${ }^{4}$, \\ Tomasz RUTKOWSKI ${ }^{5}$ and Konrad WIŚNIEWSKI ${ }^{6}$ \\ ${ }^{1}$ Department of Biodiversity \& Evolutionary Taxonomy, University of Wroctaw, Przybyszewskiego 65, 51-148 \\ Wrocław,Poland; e-mail: rafal.ruta@uwr.edu.pl \\ ${ }^{2}$ Św. Stanisława 11/5, 62-800 Kalisz; e-mail: kusakowaty@gmail.com \\ ${ }^{3}$ Department of Zoology, Faculty of Biology and Biotechnology, University of Warmia and Mazury, Oczapowskiego 5 , \\ 10-7180lsztyn, Poland; e-mail: kurcik@uwm.edu.pl \\ ${ }^{4}$ Department of Entomology and Environmental Protection, Poznan University of Life Sciences; \\ e-mail:ophonus@gmail.com \\ ${ }^{5}$ Natural History Collections, Faculty of Biology, Adam Mickiewicz University in Poznań, Umultowska 89, 61-614 \\ Poznań, Poland; e-mail: pardosa@gazeta.pl \\ ${ }^{6}$ Department of Zoology, Institute of Biology and Environmental Protection, Faculty of Mathematics and Natural \\ Sciences, Pomeranian University in Stupsk, Arciszewskiego 22b, 76-200 Stupsk, Poland; e-mail: \\ konwisniew@gmail.com
}

\begin{abstract}
Atheta strandiella is recorded in four localities in northern Poland including two Baltic raised bogs, another record comes from the south of the country, from a montane bog. The occurrence of $A$. strandiella in Poland is not surprising, as the species was already recorded from neighboring countries, including Belarus, Czechia, and Germany. Numerous findings of $A$. strandiella in different mires of Poland, including the Baltic and montane raised bogs, show our limited and insufficient knowledge of beetles inhabiting these endangered habitats.
\end{abstract}

Key words: Baltic raised bogs, montane bogs, wetlands, Stołowe Mountains, Pomerania, Sudetes

\section{INTRODUCTION}

There are over 1350 species of Staphylinidae occurring in Poland and almost every year further species are recorded (e.g. Szujecki 2013, Marczak et al. 2013, Szujecki 2014, Szołtys \& Melke 2017, Jałoszyński et al. 2018). Within the family, Atheta Thomson is one of the most speciose genera. Until now, 123 species have been recorded from Poland (Smetana 2015). During our field studies, we have recently collected Atheta strandiella in five localities.

\section{MATERIAL AND METHODS}

Samples were collected in course of different field studies conducted in the northern and southern part of Poland. In all cases, non-baited pitfall traps were used to collect beetles. Specimens are deposited in the collection of Karol Komosiński (Department of Zoology, University of Warmia and Mazury in Olsztyn) and in the collection of Rafał Ruta (Department of Biodiversity and Evolutionary Taxonomy, University of Wrocław (DBET)).

The distribution map was created with Gnomon software, photos of the beetle and its morphological structures were taken with a Nikon SMZ-1500 and Nikon Eclipse Ni microscopes combined with a Nikon D5100 digital camera. The images were generated using Helicon Focus (6.6.1 Pro) software and enhanced using Adobe ${ }^{\circledR}$ Photoshop CS4 11.0.

The regional division of Poland is adopted after the Catalogue of Polish Fauna (Burakowski et al. 1971). 


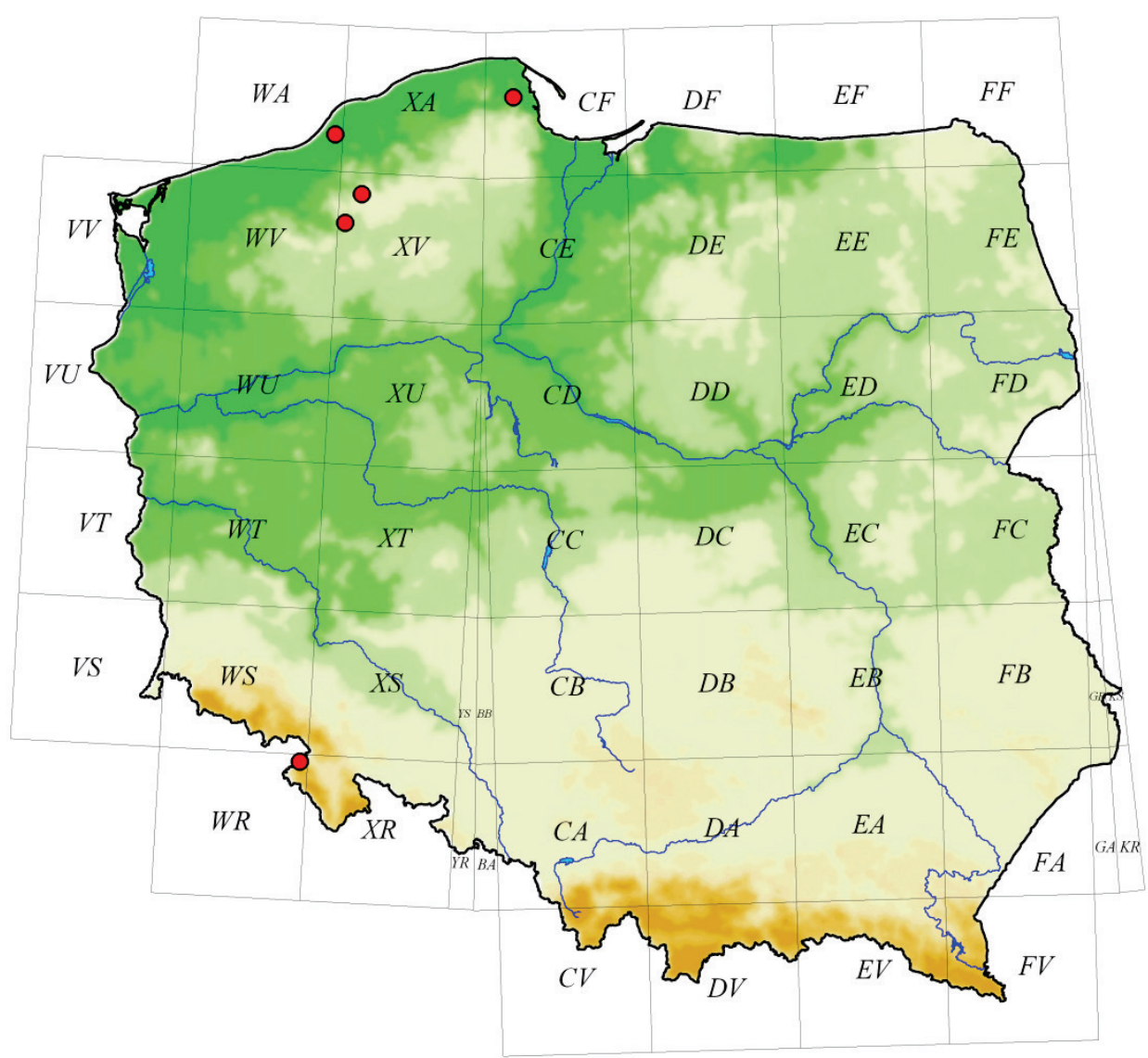

Fig. 1. Distribution of Atheta strandiella in Poland.

\section{RESUlts}

Records of Atheta strandiella Brundin, 1954 in Poland (Fig. 1):

- Baltic Coast, "Słowińskie Błota" nature reserve near Słowino (UTM code: WA92), scots pine bog woodland, $54.3605^{\circ} \mathrm{N}, 16.4817^{\circ} \mathrm{E}$, pitfall trap, 4 May-10 Jul 2017 , 1 ex., bog with low scots pines, $54.3614^{\circ} \mathrm{N}, 16.4810^{\circ} \mathrm{E}$, pitfall traps, $11 \mathrm{Jun}-$ $10 \mathrm{Jul} 2017,5$ exx., open part of a bog, $54.3621^{\circ} \mathrm{N}, 16.4797^{\circ} \mathrm{E}$, pitfall traps, $11 \mathrm{Jun}-$ 10 Jul 2017, 2 exx., leg. P. Sienkiewicz \& T. Rutkowski, coll. DBET;

- $\quad$ Pomeranian Lake District, Stoborowe lake vic., near Wejherowo (CF25), 54.6507 N, $18.2134^{\circ} \mathrm{E}, 11-25$ Jun $2006,1{ }^{\jmath}$, pitfall trap in a wet area, leg. I. Miotk, det. and coll. K. Komosiński;

- Pomeranian Lake District, "Bagno Kusowo" nature reserve ad Kusowo (XV06), scots pine bog woodland, $53.8120^{\circ} \mathrm{N}, 16.5824^{\circ} \mathrm{E}$, pitfall trap, 5 May-10 Jun 2017, 1 ex., open part of a bog, $53.8128^{\circ} \mathrm{N}, 16.58521^{\circ} \mathrm{E}$, pitfall traps, $10 \mathrm{Jun}-11 \mathrm{Jul} 2017,17$ exx., leg. P. Sienkiewicz \& T. Rutkowski, coll. DBET; 
- $\quad$ Pomeranian Lake District, vicinity of Kwiecko lake ad Żydowo (XV18), $54.0227^{\circ} \mathrm{N}$, $16.6803^{\circ} \mathrm{E}, 89 \mathrm{~m}$ a.s.l., an alkaline fen (ca $2 \mathrm{ha}$ ) in a land depression, surrounded by

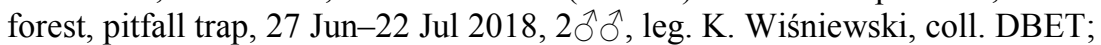

- Western Sudety Mts., Stołowe Mts. (SW Poland), "Wielkie Torfowisko Batorowskie" bog (WR99), $50.4544^{\circ} \mathrm{N}, 16.3792^{\circ} \mathrm{E}, 727 \mathrm{~m}$ a.s.l., ecotone between a bog and a spruce forest, with Vaccinium myrtillus L. and patches of Sphagnum sp. in understory, pitfall trap, 19 Jun-8 Jul 2010, 1ð, leg. K. Wiśniewski, coll. DBET.

Both "Słowińskie Błota" and "Bagno Kusowo" (Figs 2-3) nature reserves protect Baltic raised bogs, that are listed among the best preserved bogs of this type in Poland (Herbichowa et al. 2007). Beetles were collected both in open bogs and in surrounding woodlands. The third collecting site is situated on the marshy shore of Lake Stoborowe (Fig. 4), another one on a small alkaline fen, which was supposed to be included in a planned "Kwiecko" nature reserve. The only record in southern Poland comes from the "Wielkie Torfowisko Batorowskie" bog, which is protected within the Stołowe Mountains National Park (Fig. 5). This is one of the largest mires in this part of the Sudetes, and although it was largely degraded by drainage, it is still relatively well preserved.

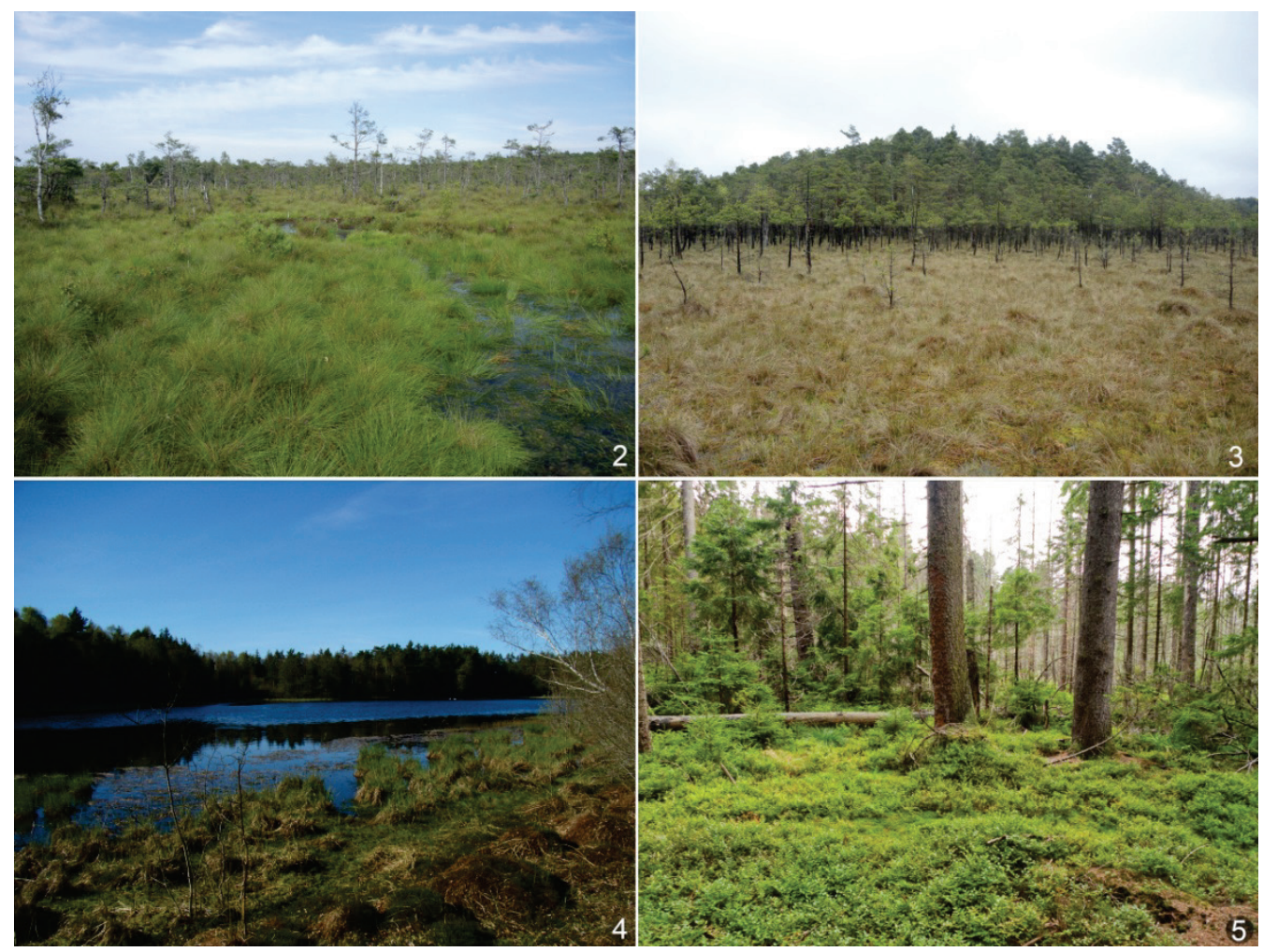

Figs 2-5. Localities of Atheta strandiella in Poland: 2 - "Słowińskie Błota" nature reserve; 3 - "Bagno Kusowo" nature reserve; 4 - Stoborowe lake; 5 - spruce forest by the "Wielkie Torfowisko Batorowskie" bog. Photos by R. Ruta (2, 3), I. Miotk (4), and K. Wiśniewski (5). 


\section{DISCUSSION}

Atheta strandiella (Figs 6-10) is widely distributed in Europe. It was recorded from Austria, Belarus, Belgium, Czechia, Denmark, Estonia, Finland, France, Germany, Great Britain, Ireland, Lithuania, the Netherlands, Norway, North European Territory of Russia, Slovakia, Sweden, and Switzerland. Its range extends eastwards to West Siberia (Sushko et al. 2008, Smetana 2015). Mossakowski et al. (2003) noticed that A. strandiella abundance decreases from west to east - the species was common in bogs studied in Germany, occurred in low numbers in Latvian bogs and was missing in Estonian localities. Our observations seem to conform to this pattern.

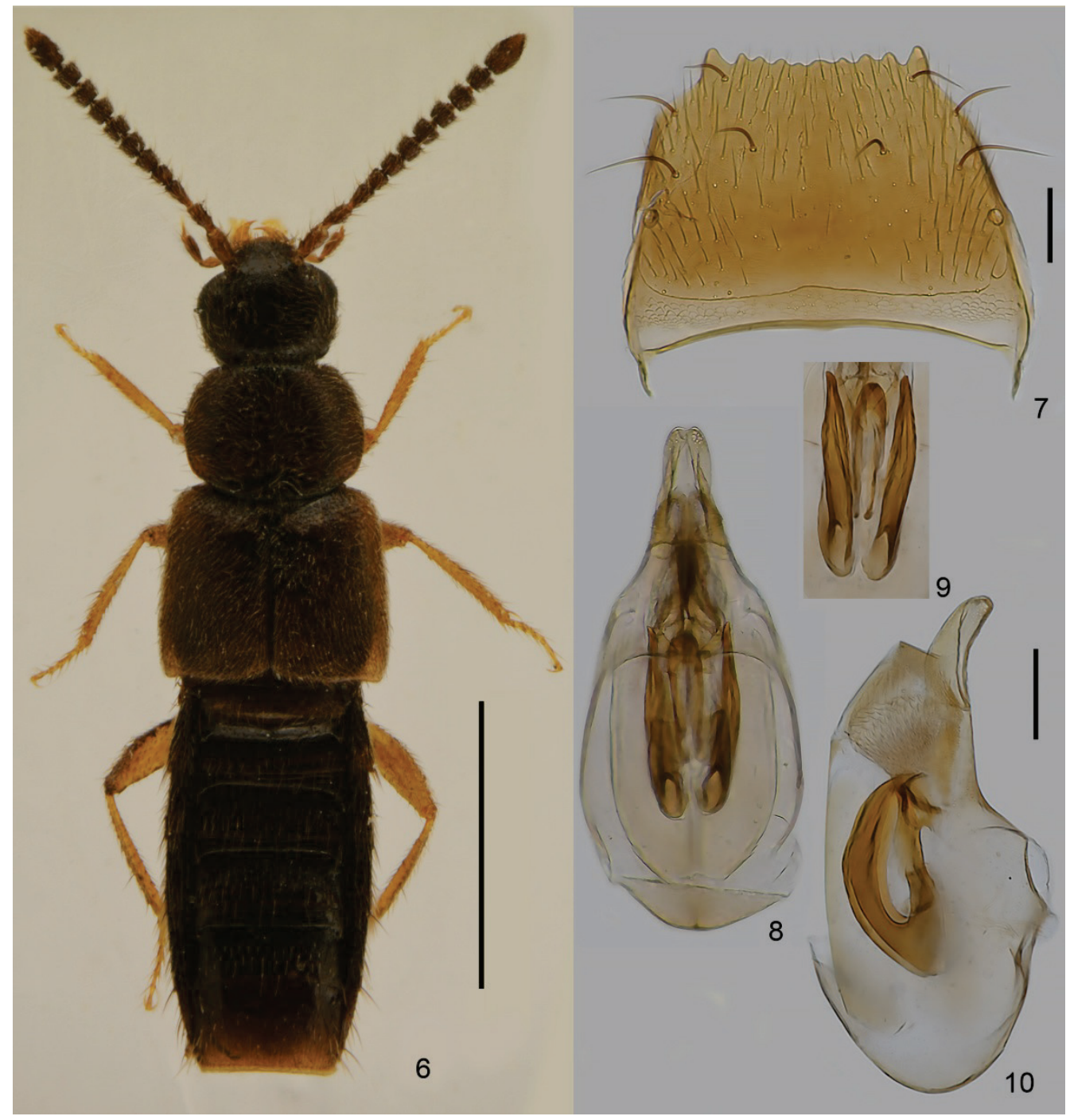

Figs 6-10. Atheta strandiella: 6 - male, dorsal view (length $2.8 \mathrm{~mm}$, scale bar $=1.0 \mathrm{~mm}$ ); 7 - tergite VIII (length 0.45 $\mathrm{mm}$, scale bar $=0.1 \mathrm{~mm}) ; 8-$ median lobe of aedeagus, ventral view (length $0.53 \mathrm{~mm}$, scale bar $=0.1 \mathrm{~mm}), 9-$ detail of internal sac of aedeagus, dorsal view, 10 - median lobe of aedeagus, lateral view. Photos by R. Ruta. 
Brundin (1954) supposed this is a eurytopic species with a boreo-alpine distribution. Knowledge of the habitat preferences and life history of $A$. strandiella is very scarce. There are numerous studies showing that the species inhabits peat bogs (Brundin 1954, Mossakowski et al. 2003, Sushko 2016) and Boyce (2004) provisionally included A. strandiella on a list of beetles associated with acid mires. Sometimes $A$. strandiella occurs in forests as well. For example in Norway, the species was collected in pitfall traps in heather pine woodland and bilberry pine woodland (Skartveit et al. 2004). Atheta strandiella was repeatedly collected on carrion (Hammond \& Bacchus 1972, Owen 1989, Good 1992), but also on dead fish (Brundin 1954), in dung (Owen 1989), and on oozing sap of a birch (Brundin 1954). In Koch (1989), based on German records, the species is described as a eurytopic hygrophil and phytodetriticol, occurring in spruce forests and mires, where it inhabits rotting materials, carrion and also Sphagnum mosses.

Atheta strandiella is included in the red lists of Germany (Geiser 1998), Denmark (Stolze \& Pihl 1998), Czechia (Farkač et al. 2005) and also in regional red lists (e.g. Esser 2017). As our knowledge on distribution and habitat requirements of the discussed species in Poland is very limited, it would be premature to consider $A$. strandiella for inclusion in the Polish Red List of Animals. The fact that A. strandiella was recorded in Poland much later than in neighboring countries shows that mires of Poland are understudied and require more attention from entomologists.

Atheta strandiella differs from other members of the Atheta crassicornis-group in the following characters: antennae are narrower, antennomere 3 is almost as long as antennomere 2. Antennomeres 6-10 are cylindrical, ca. $1.5 \mathrm{x}$ wider than long (this character is particularly well visible in males). Remaining members of the group have more robust antennae, with antennomere 3 distinctly longer than antennomere 2. Antennomeres 6-9 are more than $1.5 \mathrm{x}$ wider than long. The apex of tergite VIII of males is denticulate in all members of the group (Fig. 7), denticles are subtle in Atheta fungicola (C. G. Thomson, 1852), intermediate in $A$. strandiella and largest in A. paracrassicornis Brundin, 1954. Sternite VIII of females of $A$. strandiella is regularly semicircular, without long setae on posterior margin. Sternite VIII of females in remaining members of the group have distinct setae on posterior margin that are either yellow (Atheta britanniae M. Bernhauer et Scheerpeltz, 1926) or dark (Atheta fungicola, A. crassicornis (Fabricius, 1793), A. paracrassicornis Brundin, 1954). Atheta strandiella can be identified using the key by Freude et al. (1974), additional figures of male and female genitalia are included in the original description (Brundin 1954), Strand \& Vik (1964), and the present paper (Figs 8-10).

\section{ACKNOWLEDGEMENTS}

Survey of beetles of the "Słowińskie Błota" and "Bagno Kusowo" nature reserves was part of the project "Improvement of conservation of the most valuable raised bogs in Poland" financed by the Nature and Biodiversity Conservation Union (NABU) and carried out by the Naturalists Club (www.kp.org.pl). Our fieldwork was financially supported by the Department of Entomology and Environmental Protection, Poznan University of Life Sciences. The fen in Pomeranian Lakeland was investigated with permission of the Regional Directorate for Environmental Protection in Szczecin. The research in the Stołowe Mountains was conducted with permission and kind support of the Stołowe Mountains National Park. We also thank Ilona Miotk for providing the specimen and two anonymous reviewers for their comments. Paweł Pawlaczyk and Robert Stańko are thanked for additional data on the "Kwiecko" planned nature reserve. 


\section{REFERENCES}

BoyCE D. C. 2004. A review of the Invertebrate Assemblage of Acid Mires. English Nature Research Reports No. 592. English Nature, Peterborough, $110 \mathrm{pp}$.

BRUNDIN L. 1954. Neue palaearktische Arten der Gattung Atheta C. G. Thoms. (Col., Staphylinidae). Norsk Entomologisk Tidsskrift 9 (1-2): 1-17.

Burakowski B., Mroczkowski M. \& Stefańska J. 1971. Chrząszcze Coleoptera. Biegaczowate - Carabidae. 1. Katalog Fauny Polski, XXIII, 2. PWN, Warszawa, 234 pp.

ESSER J. 2017: Rote Liste und Gesamtartenliste der Kurzflügelkäferartigen und Stutzkäfer (Coleoptera: Staphylinoidea und Histeridae) von Berlin. In: Rote Listen der gefährdeten Pflanzen, Pilze und Tiere von Berlin, 57 pp. DOI: 10.14279/depositonce-5852

FARKAČ J., KRÁL D. \& ŠKORPÍK M. 2005. Červený seznam ohrožených druhů České republiky. Bezobratlí. List of threatened species in the Czech Republic. Invertebrates. - Agentura ochrany př́rody a krajiny ČR, Praha, $760 \mathrm{pp}$.

Freude H., Harde K. W. \& Lohse G.A. 1974. Die Käfer Mitteleuropas. Band 5. Staphylinidae II (Hypocyphtinae und Aleocharinae), Pselaphidae. Goecke \& Evers, Krefeld, 381 pp.

Geiser R. 1998. Rote Liste der Käfer (Coleoptera) In: BinOt M., Bless R., Boye P., GruttKe H., Pretscher P.: Rote Liste gefährdeter Tiere Deutschlands. Schriftenreihe für Landschaftspflege und Naturschutz 55: 168-230.

Good J.A. 1992. Atheta strandiella Brundin (Coleoptera: Staphylinidae), a necrophilous beetle new to Ireland. Irish Naturalists' Journal 24: 79.

HAMMOND P. M. \& BACChUS M. E. 1972. Atheta (s. str.) strandiella Brundin (Col., Staphylinidae) new to the British Isles, with notes on other British species of the subgenus. Entomologist's Monthly Magazine 107: 153-157.

Herbichowa M., PawlaczyK P. \& Stańko R. 2007. Conservation of Baltic raised bogs in Pomerania, Poland. Experience and Results of the LIFE04NAT/PL/000208 PLBALTBOGS Project. Naturalists Club Poland, 148 pp.

JAŁOSZYŃSKI P., MElKe A. \& WiŚNIEWSKI K. 2018. Euaesthetus superlatus Peyerimhoff, 1937 (Coleoptera: Staphylinidae), kusak nowy dla Polski. Acta Entomologica Silesiana 26 (online 010): 1-4. DOI: 10.5281/zenodo. 1208348

Kосн K. 1989. Die Käfer Mitteleuropas. Ökologie. Band 1. Goecke \& Evers, Krefeld, 440 pp.

MarczaK D., Melke A. \& Masiarz J. 2013. Calodera cochlearis Assing, 1996 (Coleoptera: Staphylinidae) gatunek nowy dla fauny Polski oraz inne gatunki rzadkich kusakowatych nowe dla Niziny Mazowieckiej. Wiadomości Entomologiczne 32 (3): 165-178.

MossAKOWSKI D., FrÄMBS H. \& LAKOMY W. 2003. The Carabid and Staphylinid fauna of raised bogs. A comparison of Northwest Germany and the Baltic region. Baltic Journal of Coleopterology 3 (2): 137-144.

OWEN J. A. 1989. Atheta strandiella Brundin (Col. Staphylinidae) in Norfolk, East Inverness, Wester Ross and Shetland. Entomologist's Record 101: 88-89.

SkartVeit J., Pommeresche R. \& Solhøy T. 2004. Notes on uncommon beetles (Coleoptera) collected during a survey in Hardanger, Western Norway. Norwegian Journal of Entomology 51: 151-158.

SmetanA A. 2015. Staphylinidae. Pp. 304-1135. In: LöBL I. \& LöBL D. (eds): Catalogue of Palaearctic Coleoptera, Volume 2. Revised and Updated Edition. Hydrophiloidea - Staphylinoidea, Brill, 1702 pp.

Stoltze M. \& PiHL S. (ed.) 1998. Rødliste 1997 over planter og dyr i Danmark. Miljø- og Energiministeriet, Danmarks Miljø- undersøgelser og Skov- og Naturstyrelsen, 220 pp.

Sushko G. G., Solodovnikov I. A. \& Zhukov L. P. 2008. New and little known species of Coleoptera of raised bogs of Lake District, pp. 224-225. In: DoRofeEv A. M. (ed.) Biological Diversity of the Belarusian Lake District: Proceedings of the II International Scientific Conference, Vitebsk, 19-21 November 2008. Vitebsk State University Press, Vitebsk, $291 \mathrm{pp}$

SushKo G. G. 2016. Species composition and zoogeography of the rove beetles (Coleoptera: Staphylinidae) of raised bogs of Belarus. North-Western Journal of Zoology 12 (2): 220-229.

SzoŁtYs H. \& MELKe A. 2017. Nowe dla fauny Polski gatunki chrząszczy z rodziny kusakowatych (Coleoptera: Staphylinidae). Acta Entomologica Silesiana 25 (online 034): 1-3. DOI: 10.5281/zenodo.1018686

STRAND A. \& VIK A. 1964. Die Genitalorgane der nordischen Arten der Gattung Atheta Thorns. (Col., Staphylinidae). Norsk Entomologisk Tidsskrift 12: 327-335+ 21 plates.

SZUJECKI A. 2013. Mycetoporus montanus Luze, 1901 (Coleoptera: Staphylinidae: Tachyporinae) w Polsce! Wiadomości Entomologiczne 32(2): 85-88.

SzUJECKI A. 2014. Sepedophilus wankowiczi (Pandellé, 1869) (Coleoptera: Staphylinidae) w Białowieskim Parku Narodowym. Wiadomości Entomologiczne 33(2): 152. 


\section{STRESZCZENIE}

[Atheta strandiella Brundin, 1954 (Coleoptera: Staphylinidae) - gatunek nowy dla Polski]

W latach 2006-2018 na czterech stanowiskach w północnej Polsce oraz jednym w Sudetach odnaleziono Atheta strandiella. Gatunek ten jest szeroko rozmieszczony w Europie, znany był do tej pory ze Skandynawii, Litwy, Estonii, Łotwy, Białorusi, Rosji, Czech, Słowacji, Niemiec, Austrii, Danii, Holandii, Belgii, Francji, Wielkiej Brytanii i Irlandii. Preferuje siedliska wilgotne, zwłaszcza torfowiska sfagnowe. W dwóch przypadkach polskie stanowiska zlokalizowane były na terenie rezerwatów przyrody chroniących torfowiska wysokie typu bałtyckiego: „Bagno Kusowo” i „Słowińskie Błota”, natomiast „Wielkie Torfowisko Batorowskie” jest chronione w obrębie Parku Narodowego Gór Stołowych. 